"The perception of Islamic banking by the first national bank sales staff in the Kwazulu-Natal region of South Africa"

\begin{tabular}{ll} 
AUTHORS & $\begin{array}{l}\text { Ismail Vahed } \\
\text { Muhammad Ehsanul Hoque }\end{array}$ \\
Ismail Vahed and Muhammad Ehsanul Hoque (2016). The perception of Islamic \\
ARTICLE INFO & $\begin{array}{l}\text { Africa. Banks and Bank Systems, 11(4), 50-60. doi:10.21511/bbs.11(4).2016.05 } \\
\text { DOI }\end{array}$ \\
\hline hELEA://dx.doi.org/10.21511/bbs.11(4).2016.05 \\
\hline JOURNAL & Friday, 09 December 2016 \\
\hline FOUNDER & "Banks and Bank Systems" \\
\hline
\end{tabular}

NUMBER OF REFERENCES

0

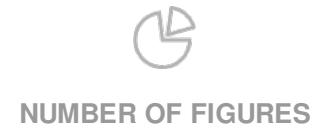

0

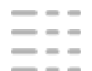

NUMBER OF TABLES

0

(C) The author(s) 2023. This publication is an open access article. 
Ismail Vahed (South Africa), Muhammad Ehsanul Hoque (South Africa)

\title{
The perception of Islamic banking by the first national bank sales staff in the Kwazulu-Natal region of South Africa
}

\begin{abstract}
The objective of this study is to determine the perception and awareness of Islamic banking by a conventional banks sales force. This was a cross-sectional study conducted among 100 sales staff randomly selected to take part in the study. A self-administered anonymous questionnaire was used to collect the data using online system called QuestionPro. Results revealed that whilst the respondents did feel there was a need for Islamic banking, they also did feel that Islamic banking was more complicated than conventional banking. The study also revealed that there was an overall negative perception of Islamic banking which was primarily based on a lack of knowledge, awareness, and understanding. It is recommended that banks provide sufficient and effective training to their staff on all products and services so that any negative perception can be eliminated. This study can benefit organizations that are in the Islamic banking industry or looking at getting into the Islamic banking industry.
\end{abstract}

Keywords: Islamic banking, conventional banking, knowledge, perception, training. JEL Classification: G21, D83.

\section{Introduction}

Islamic banking is the fastest growing sector within the financial industry with a year on year growth of between 15-20 per cent (Ernst \& Young, 2013). The Islamic financial sector has been extremely resilient through the recent global recession and according to DCIBF Annual Report 2014, the Islamic financial industry will be worth over $\$ 5$ trillion by 2020 if it continues growing as per previous years (HBMSU, 2014). The number of Islamic banks and Islamic windows has grown significantly over the last few years with the total number of more than 626 and operating in over 48 countries (Sanusi, 2011). The growth is not only being driven in Muslim countries, but also in nonMuslim countries with many Western countries aiming at being at the forefront of this lucrative market. Due to the demand for Shariah (Islamic) compliant products and the desire to lure Islamic investments, conventional banks have recognized the importance of the Islamic banking sector and have started to offer Islamic banking products through Islamic branches, Islamic subsidiaries or Islamic windows. One of the main challenges specifically for Islamic windows is that the majority of the sales force is non-Muslim and this can pose a challenge for the Islamic window to effectively sell and market its products.

FNB Islamic banking (FNBI) is a "window" within the conventional FNB (First National Bank) and provides Shariah compliant banking and lending to those clients that want to avail to this type of niche banking. FNBI was the first of the major conventional banks in South Africa to start offering Islamic banking products and services.

(c) Ismail Vahed, Muhammad Ehsanul Hoque, 2016.

Ismail Vahed, Graduate School of Business and Leadership, University of KwaZulu-Natal, South Africa.

Muhammad Ehsanul Hoque, Ph.D., Academic Leader: Higher Degrees and Research, Graduate School of Business and Leadership, University of KwaZulu-Natal, South Africa.
FNBI follows a hybrid model in that it has product house (develops products) and distribution (fulfilment) capabilities for the various products that it offers. For some of their products, FNBI has to rely on other areas to sell, do fulfilment and manage its clients. These Islamic products are not limited to only Muslim staff to sell and are available to non-Muslim staff as well. The hybrid model does have many advantages, however, it does pose many challenges for FNBI such as: FNBI is reliant on other business units to achieve their sales targets, FNBI does not have its own fulfilment capabilities, and lack of accountability by distribution channels such as the branch network, FNBI is perceived to be a product offering that is in competition with the conventional product, as opposed to a complimentary product offering.

FNBI is reliant on the branch network to sell its products and manage its client base. Given that FNBI falls under the Islamic window structure, its products and service are offered through the distribution channels of the conventional bank. This means that the products and services will be sold by staff that are not part of Islamic banking and who are mostly non-Muslims. If the sales force has a negative perception of Islamic banking, then, this would be detrimental for the growth and success of the Islamic banking business. Therefore, it is necessary to investigate the perception of the sales force at FNB to determine whether it is negative or not. Therefore, this study seeks to shed light on the perception and awareness of Islamic banking by the sales force of FNB.

\section{Literature review}

1.1. Islamic economic system. The conventional economic system is based on interest which has resulted in wealth being concentrated to a select few. This has created monopolies and has widened the gap between the rich and the poor (Usmani, 2002). Conventional systems are governed by man and, as 
such, are open to abuse. In Western economic philosophy it is regarded that man is inherently selfish who acts in his own interest before anyone else (Presley and Sessions, 1994). An Islamic economic system, on the one hand, is an economic system that must conform to Shariah and is derived from Divine Law, not manmade. Islamic economics, according to Mohsin S. Khan, a senior economist at the IMF, is defined as "a complete system that prescribes a specific pattern of social and economic behavior for all individuals. It deals with a wide-ranging set of issues, such as property rights, incentive system, allocation of resources, types of economic freedom, system of economic decision-making and proper role of the government. The over-riding objective of the system is social justice and specific patterns of income and wealth distribution and, consequently, economic policies are to be designed to achieve these ends". On the other hand, S.M. Hasanuz Zaman, an IDB Laureate in Islamic economics, defines it as follows "Islamic economics is the knowledge of application of injunctions and rules of the Shariah that stop injustice in the acquisition and disposition of material resources in order to provide satisfaction to individuals and enable them to perform their obligations to Allah and society" (Ayub, 2007).

Economic justice requires that the economic system be viable and be supported by an efficient banking system. According to Usmani (2002), the current banking system that is based on interest has proved to be inefficient, as it promotes economic injustice and sociably irresponsible banking. Islamic banking, on the other hand, promotes efficient and socially responsible banking through its principles and product structures. The Islamic economic system promotes economic justice through the manner in which the distribution of wealth occurs.

Capitalism is a system of social organization by which private money-making is its chief end (Cahn, 2012). It gives man the absolute and unconditional right to private property and wealth. Socialism, on the other hand, is based on the public ownership and gives man no right to private property. Socialism and capitalism are the only economic systems that have been created by man, whereas Islam is a complete way of life which incorporates economics. Islam lies somewhere in-between capitalism and socialism, as it acknowledges the right to private property and freedom of trade, but doesn't allow unconditional and unrestricted use of this property or wealth. In Islamic economics, although livelihood is necessary and cannot be ignored, it is a means of achieving success in the hereafter and not the sole purpose of human life. On the other hand, in conventional economics, livelihood is a significant problem and economic growth is the goal of human life. This is the fundamental difference between the conventional and Islamic systems.
1.2. Islamic financial systems. An Islamic financial system cannot be simply referred to as a system that is free from interest. Whilst the prohibition of interest is at the centre of the system, there are other principles that need to be supported to ensure that the system can be Shariah compliant. To promote fairness and equality in dealings, the Islamic financial system places emphasis on the social, religious, moral and ethical dimensions as well. The system also takes into account wealth distribution, economic and social justice, work ethic and the role of the state. Shariah Law has set down the framework for an Islamic financial system and according to the Institute of Islamic Banking \& Finance and Shanmugam and Zahari (2009), the following are the main principles: Prohibition of Interest, Risk Sharing, Prohibition of Gharar (speculative behavior), Sanctity of the contract, Shariah approved activities (Institute of Islamic Banking and Insurance, 2015)

The main difference between the conventional and the Islamic financial system is that the Islamic system is an ethical system which leads to a social obligation of ensuring that all parties benefit from the transaction. The relationship between the client and the bank is very different to that of a conventional system. In the Islamic system, the client and bank have a partnership relationship, whereas with the conventional system, the relationship is that of a creditor-investor (Venardos, 2005).

1.3. Islamic banking. Islamic economics and financial systems are very different to its conventional counterparts. Islam is a way of life and promotes justice and equality in all aspects of life including banking. When Islamic banking also known as Islamic finance was initially launched, many thought it was the same as conventional banking minus the word "interest", however, Islamic banking is more than changing terminology or structures (AbdulRahman, 2010). According to Shanmugam and Zahari (2009), Islamic banking and finance refers to "financial market transactions, operations, and services that comply with Islamic rules, principles, and codes of practice". The values and belief system of Islam guide the way that Islamic transactions are done. In other words, Islamic banking is a faith based form of banking, as it bases all of its activities on Shariah Law.

The Islamic financial sector has been extremely resilient through the recent global recession and whilst most conventional banks were posting poor results, Islamic banks were posting good growth in their net profit positions. Islamic banking is not much different from conventional banking in terms of their objectives. The difference being that Islamic banks have to conduct all their affairs within the ambit of Shariah Law. The number of Islamic banks and Islamic windows has grown significantly over the last few years with the 
total number of more than 626 and operating in over 48 countries (Sanusi, 2011). The growth is not only being driven in Muslim countries, but also in nonMuslim countries with many Western countries aiming at being at the forefront of this lucrative market. The UK is hoping to be the leading hub in Islamic banking globally and hopes to be the first Western country to issue a sovereign Sukuk (Islamic bond) (Vizcaino, 2013). The reason for this growth can be attributed to the fact that Islam is the fastest growing religion in the world and this niche market is extremely lucrative and relatively untapped.

Due to the competitiveness of the financial industry, the demand for Shariah compliant products and the desire to lure Islamic investments,

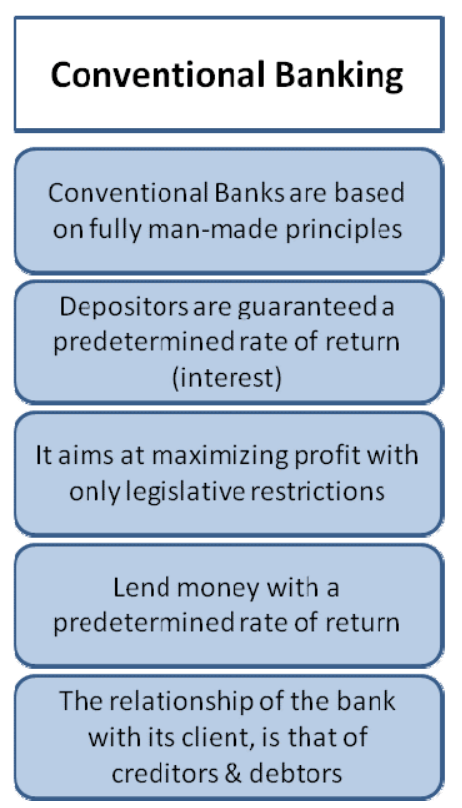

conventional banks have recognized the importance of the Islamic banking sector and have started to offer Islamic banking products through Islamic windows. Major global banks such as HSBC \& Standard Chartered have Islamic windows and the growth in the number of Islamic windows has been phenomenal with over 191 Islamic Windows offering Islamic products $(\mathrm{Sa}-$ nusi, 2011). The Islamic financial sector has been extremely resilient through the recent global recession and according to DCIBF Annual Report 2014 , the Islamic financial industry will be worth over $\$ 5$ trillion by 2020 if it continues growing as per previous years (HBMSU, 2014). The following Figure 1 summarizes the key differences between Islamic and conventional banking.

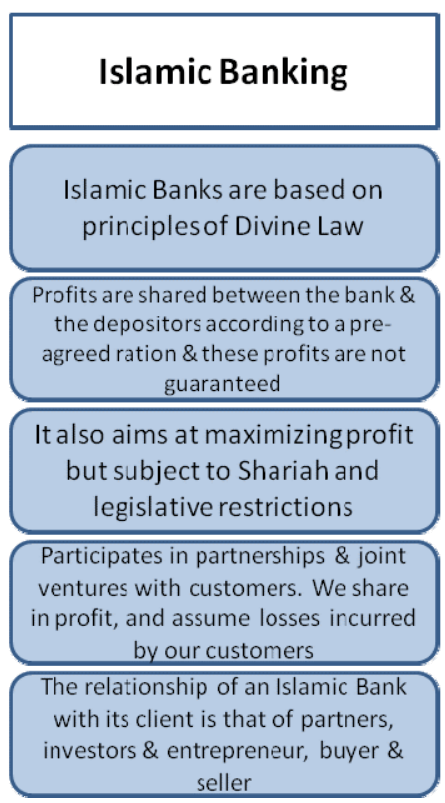

Fig. 1. Key differences between Islamic and conventional banking

Source: Adapted from Suliman (2015).

In Figure1 above, it can be seen that whilst Islamic banking is also about maximizing profits, it has to do this within the legal and Shariah framework. Another key difference between Islamic banking and conventional banking is that there can be no guaranteed rate of return for the depositor and when Islamic banks lend money to their clients, there is more risk compared to that of the conventional bank, as Islamic banks can also share in the losses incurred by its customers.

1.4. Perception and awareness of Islamic banking. When it comes to selling any products and services, the attitude of the individual is critical for its success. According to Haque (2009), attitude is an extremely important aspect in predicting and understanding the way customers behave in certain situations. According to Azjen (1982), most social psychologists view attitude as "a predisposition to respond in a generally favorable or unfavorable manner with respect to the object of the attitude". This means that the attitude of a person influences the perception of that person.
A simple definition of perception is "the way that you notice or understand something using one of your senses" (Merriam-webster.com, 2015). However, a more detailed definition, according to Rao and Narayana (1987), from a psychology perspective, is that "perception is the process whereby people select, organize, and interpret sensory stimulations into meaningful information about their work environment". They further state that "there can be no behavior without perception" and that the most important factor in determining human behaviour is perception. This means that to effectively sell products, the sales force needs to have a positive perception of the products and services that they are marketing. According to Wisegeek (2015), perception regarding a product is defined as determining the way that customers think and respond to the various types of goods and services available. All companies want to have a positive perception of their products that are offered to their customer, because it has an impact on the bottom line. 
A customer is someone that buys goods or services from a seller (Investorwords, 2015). Customers can be categorized as both external and internal. An external customer merely utilizes the products and services and is not part of the company. They are essential to the success of the company, as they provide the revenue. For instance, an external customer is someone who opens a bank account at a branch or someone who buys shoes from a shop. An internal customer, on the other hand, is part of the company and requires the assistance of others so that they can fulfil their duties. Whilst they do not directly buy the products, their interactions and dealings with the external customer affect the bottom line.

For instance, an internal customer is the employee that opens the account for the external customer (Joseph, 2015). For the purpose of this literature review, when we refer to customer, we are referring to the internal customer, i.e., employee. According to Allison (2012), any breakdown with the internal customer has a direct impact on the external customer. For a company to be successful, the reality is that the company should satisfy the needs of the internal customer if they wish to meet the needs of their external customers. To ensure that the internal customer's needs are satisfied, one of the key elements is that training on the products and services for the employees is to be conducted. By increasing the knowledge and understanding of the product, it will give the employee greater awareness of the product and increased confidence to meet the external customers needs (Farias, 2010).

The perception and attitude of a customer has a significant impact on a Islamic banks survival (Hassan \& Kabir, 2011). Islamic banking products and service are sold by both a sales force that comprises of both Muslim and non-Muslim employees, Islamic banks need to put an extra effort in trying to modify or reinforce the perception of Islamic banking (Haque, 2010). Islamic banking is a change from the conventional way of banking in that it needs to conform to Shariah Law. The fact that it is also labelled as a religious offering leads to the perception that the product is only for Muslims or cannot be sold by non-Muslims sales staff. However, this is not the case, as Islam is a religion for all and the fact that it is labelled as "Islamic" is irrelevant, as the offering is an ethical and socially responsible way of banking.

Islamic banks need to continuously create awareness through internal marketing, by ensuring the frontline sales staff have sufficient education and knowledge on the products and services. According to the research done by Hamid and Nordin (2001), education on Islamic banking is extremely important, as customers have very limited knowledge and understanding of
Islamic banking. In their study, they found out that over 60 per cent of the respondents did not know the difference between conventional and Islamic banking products and services. In another study that was conducted by Hassan and Ahmed (2002) on employees in an Islamic bank in Bangladesh, it was found that the respondents were not willing to do Islamic transactions, as they felt that whilst the name reflected an Islamic bank, that interest was still being practiced. This again came down to the lack of understanding of the principles, values and concepts of Islamic banking. In the above cases, recommendation was given that adequate training was needed to be provided to the employees so that their understanding and perception changes (Arshad et al., 2011).

\section{Research methodology}

2.1. Research design. According to Sekaran and Bougie (2013), descriptive research is a study that is used to describe and specifically in this study, the researcher is trying to describe the respondents perception and knowledge of Islamic banking. This research aims at obtaining data from a group of individuals through a structured approach so that a collective conclusion may be drawn. Therefore, for the purpose of this study, the researcher conducted a descriptive study using a quantitative approach, as this would be the most suitable approach.

2.2. Population and sample. For the purpose of this research, the relevant population consisted of employees of First National Bank (FNB) whose job role is to sell the bank products and services. The reason for choosing the sales staff for this study is because they would be familiar and have knowledge of all the banks products and services. Secondly, these are the individuals that decide whether to offer clients the Islamic banking offering or not and, finally, the respondents will be from different branches around the KwaZulu-Natal region which will give good access to the various cultural, race and religious groups.

As part of this quantitative study, the researcher used a simple random sampling design, as every member in the population will have a known and equal chance of being selected to complete the questionnaire (Sekaran and Bougie, 2013). This technique allows every sales staff in the KwaZulu-Natal region to have an equal chance or have the same probability of being selected during the sampling process. The sampling process involves randomly selecting sales staff from various branches within the KwaZulu-Natal region. According to Sekaran and Bougie (2013), simple random sampling offers the most amount of generalizability of the population with the least amount of bias. For this study, a sample size of 100 employees were selected from a total of 325. According to Sekaran and Bougie (2013), "sample sizes larger than 30 and less than 500 are appropriate for most research". 


\subsection{Research instrument/data collection} method. For the purpose of this study, a questionnaire was used to collect the data. The questions cover areas such as the perception and knowledge of Islamic banking. All the questions were measured using the five-point Lickert scale (Strongly Disagree; Disagree; Neutral/Unsure; Agree; Strongly Agree). According to LaMarca (2011), the advantages of using a Likert scale method is that they are universal when it comes to surveys which means that it is easy for the participant to understand. The researcher conducted pilot testing with 3 sales staff members at the FNB Umhlanga offices to test the validity of the questionnaire. After taking into account the feedback from the pilot study, the final version of the questionnaire was sent to 100 employees at various FNB branches via email. The questionnaire was set up on an online website called QuestionPro. Participants were emailed a covering letter and the link for them to complete the questionnaire online. The respondents were given 14 days to complete the questionnaire with a reminder being sent through after 7 days.

2.4. Ethical issues. The ethics committee of the University of KwaZulu-Natal approved the study. The researchers also obtained permission letter from the banks. Before completing the questionnaire, participants were asked to indicate that they consent to participate in the study. Participation in the study was voluntary and participants could withdraw from the study any time they wished without any consequences. Anonymity and confidentiality was maintained at all times.

2.5. Data analysis. Once the questionnaires had been completed, the data were checked for completeness and any outliers, inconsistencies or blank responses which, if occurred, were handled in a consistent and specific manner. Descriptive summary statistics such as frequency distribution was calculated for categorical variables. Results are presented using tables or figures.

\section{Results \& discussion}

The present study investigated FNB sales forces perception with regards to Islamic banking. Sales staff at the branch level have a suite of products that they offer existing and potential clients. Islamic banking products and services are, in essence, just another offering that is on the shelf of products that FNB sales staff can offer clients. There should be no difference in terms of reward and recognition that the sales staff receives if they sell the Islamic banking offering or not. This essentially means that there should be no arbitrage between Islamic and conventional banking products. The goal of the sales staff is to offer the client the right product to suite that particular client needs.

There were 12 Likert-type statements that were asked to the respondents regarding Islamic banking products and services. Summary of all the statements is shown in Table 1 below.

Table 1. Perception regarding Islamic banking products and services

\begin{tabular}{|c|c|c|c|c|c|}
\hline Statement & SD & $\mathrm{D}$ & $\mathrm{N}$ & A & SA \\
\hline There is a need for Islamic banking products \& services & 3.4 & 5.2 & 20.7 & 31.0 & 39.7 \\
\hline It's important to provide products and services that meet the needs of a client & 3.4 & 0.0 & 1.7 & 24.1 & 70.7 \\
\hline $\begin{array}{l}\text { You would offer a client a product that suits his need although the revenue to the bank may } \\
\text { be lower on that particular product }\end{array}$ & 0.0 & 8.9 & 16.1 & 39.3 & 35.7 \\
\hline The clients religious needs should be catered for by FNB & 3.4 & 6.9 & 15.5 & 32.8 & 41.4 \\
\hline The client benefits by using Islamic banking products \& services & 1.8 & 3.6 & 21.4 & 37.5 & 35.7 \\
\hline There is any benefit for FNB by offering Islamic banking products \& services & 1.8 & 5.3 & 15.8 & 36.8 & 40.4 \\
\hline You receive any benefit for selling Islamic banking products \& services & 3.4 & 17.2 & 27.6 & 31.0 & 20.7 \\
\hline You sell Islamic banking products \& services only to Muslims & 3.4 & 24.1 & 31.0 & 29.3 & 12.1 \\
\hline FNB should have Islamic banking products specifically for Muslim clients & 8.8 & 29.8 & 22.8 & 28.1 & 10.5 \\
\hline Islamic banking provides FNB with a competitive edge in the market & 1.7 & 3.4 & 24.1 & 36.2 & 34.5 \\
\hline Muslim clients want to use Islamic banking products \& services & 0.0 & 6.9 & 24.1 & 44.8 & 24.1 \\
\hline You ever sold an Islamic banking product or service & 8.6 & 20.7 & 6.9 & 31.0 & 32.8 \\
\hline
\end{tabular}

Source: *SD = Strongly Disagree, $\mathrm{D}=$ Disagree, $\mathrm{N}=$ Neutral, A = Agree, $\mathrm{SA}=$ Strongly Agree.

Results had shown that majority of the respondents agreed or strongly agreed to most of the statements. $70.7 \%$ of the participants agreed that there is a need for Islamic banking products and services. This means that the sales staff understand that there is some benefit of having this offering in their arsenal of products. It could be because having this offering will give them a competitive edge in the market place, as not all conventional banks offer Islamic banking. Most of the respondents $(>70 \%)$ positively reported that they would offer a client a product that suits their need, although the revenue to the bank may be lower on that particular product, and the clients religious needs should be catered for by FNB. This was no surprise that the sales staff that do not offer clients products that meet their needs will eventually lose the customer to a competitor bank. 
Table 2. Perception regarding islamic banking

\begin{tabular}{|l|c|c|c|c|c|}
\hline \multicolumn{1}{|c|}{ Statements } & SD & D & N & A & SA \\
\hline Islamic banking products are similar to conventional banking products & 5.3 & 28.1 & 26.3 & 36.8 & 3.5 \\
\hline Islamic banking products \& services are complicated & 10.3 & 22.4 & 32.8 & 22.4 & 12.1 \\
\hline Management promote the selling of Islamic banking products \& services & 6.9 & 15.5 & 32.8 & 27.6 & 17.2 \\
\hline
\end{tabular}

Source: *SD = Strongly Disagree, $\mathrm{D}=$ Disagree, $\mathrm{N}=$ Neutral, $\mathrm{A}=$ Agree, $\mathrm{SA}=$ Strongly Agree.

Based on the findings presented in Table 2, just over $40 \%$ stated that it is similar to conventional banking, whilst 33.4 percent disagreed with this statement. Another (35\%) respondents agreed or strongly agreed that Islamic banking products \& services were complicated. If sales staff find a product to be complicated, they tend to not actively promote the product and only provide it if it is requested by the customer. Less than half of the participants $(45 \%)$ indicated that management promote the selling of Islamic banking products
\& services. As management have a direct influence in driving the sales forces behavior, it would seem that training and brand awareness is not only needed at sales staff level, but also at their level. To get buy-in at the sales level, it is imperative to get buy-in at management level as well.

4. Knowledge and awareness of Islamic banking. This section asks question related to the awareness and knowledge of Islamic banking products by the sales staff.

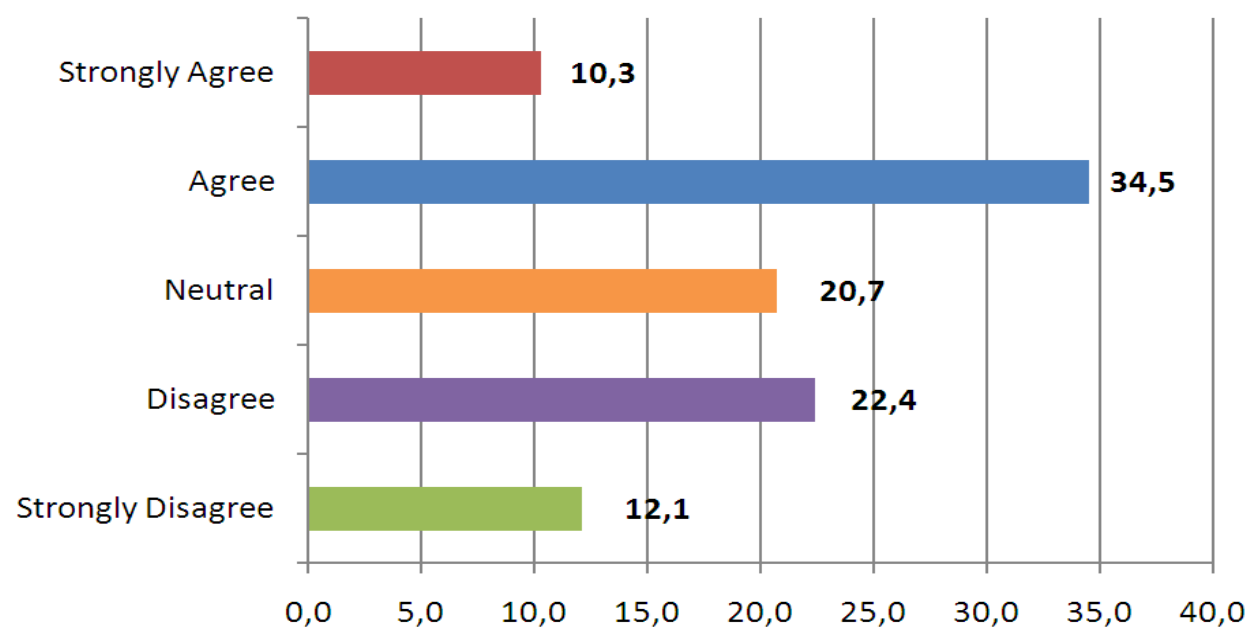

Fig. 1. Have a good understanding of Islamic banking products and services

Based on the finding depicted in Figure 2, whilst 44.8 per cent of the respondents have a good understanding of Islamic banking products and services, over half $(55.2 \%)$ did not have a good understanding or were neutral in their understanding. The lack of understanding of the Islamic banking products and services will hamper growth as sales staff find it easier to sell products that they understand.

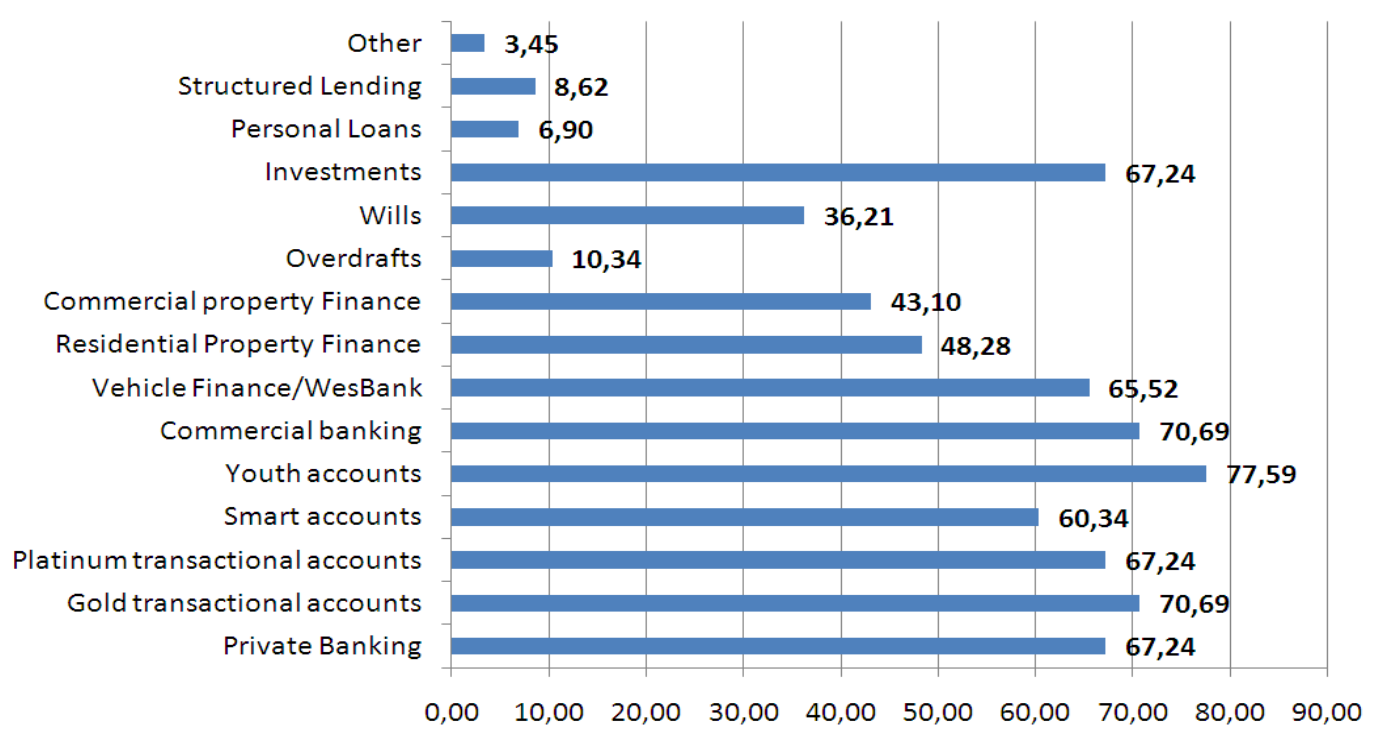

Fig. 3. Which of the following products does FNB Islamic banking offer 
Figure 3 shows the summary of the products that the respondents believe that FNB Islamic banking offers. It was found that the majority of the respondents reported that FNB offered transactional banking accounts such as youth accounts (78\%), commercial banking (71\%), platinum accounts $(67 \%)$, private banking $(67 \%)$, and gold transactional accounts $(71 \%)$. The data also revealed that $65.5 \%$ of the respondents selected vehicle finance as well and the above analysis is not surprising given that transactional banking and vehicle finance are the two longest standing products offered by Islamic banking. However, what was surprising is that although Islamic banking does not offer overdrafts $(10 \%)$, personal loans (7\%), and structured lending (9\%), a small number of respondents mentioned that this was offered.

Table 3. Types and frequency of Islamic banking products and services sold

\begin{tabular}{|l|c|c|c|c|}
\hline \multirow{2}{*}{\multicolumn{1}{|c|}{ Product }} & \multicolumn{3}{c|}{ Frequency } \\
\cline { 2 - 5 } & Daily & Weekly & Monthly & Less than once a year \\
\hline Private banking accounts & 5.4 & 1.8 & 16.1 & 76.8 \\
\hline Gold transactional accounts & 1.8 & 9.1 & 10.9 & 78.2 \\
\hline Platinum transactional accounts & 3.6 & 9.1 & 10.9 & 76.4 \\
\hline Smart accounts & 5.5 & 12.7 & 18.2 & 63.6 \\
\hline Youth accounts & 5.4 & 10.7 & 23.2 & 60.7 \\
\hline Commercial accounts & 1.9 & 1.9 & 11.1 & 85.2 \\
\hline Vehicle finance/WesBank & 3.6 & 3.6 & 5.5 & 87.3 \\
\hline Residential property finance & 1.8 & 5.5 & 0.0 & 92.8 \\
\hline Commercial property finance & 0.0 & 5.5 & 0.0 & 94.5 \\
\hline Investments & 8.9 & 10.7 & 10.7 & 69.6 \\
\hline Wills & 0.0 & 5.5 & 0.0 & 94.6 \\
\hline
\end{tabular}

The analysis in Table 3 shows that very few of the respondents indicated that they sold the Islamic products daily. Given that this is a niche market and that Muslims are a minority in South Africa, this is not surprising. What is concerning though is that majority of the products are sold less than once a year. The reasons for this could be that they do not want to sell Islamic banking products, a lack of understanding discourages them from selling the products or they are unaware Islamic banking is offered at FNB. Whatever the reason, for Islamic banking to be successful within FNB, as well as within the Islamic banking industry, the frequency of their products being sold will need to increase.

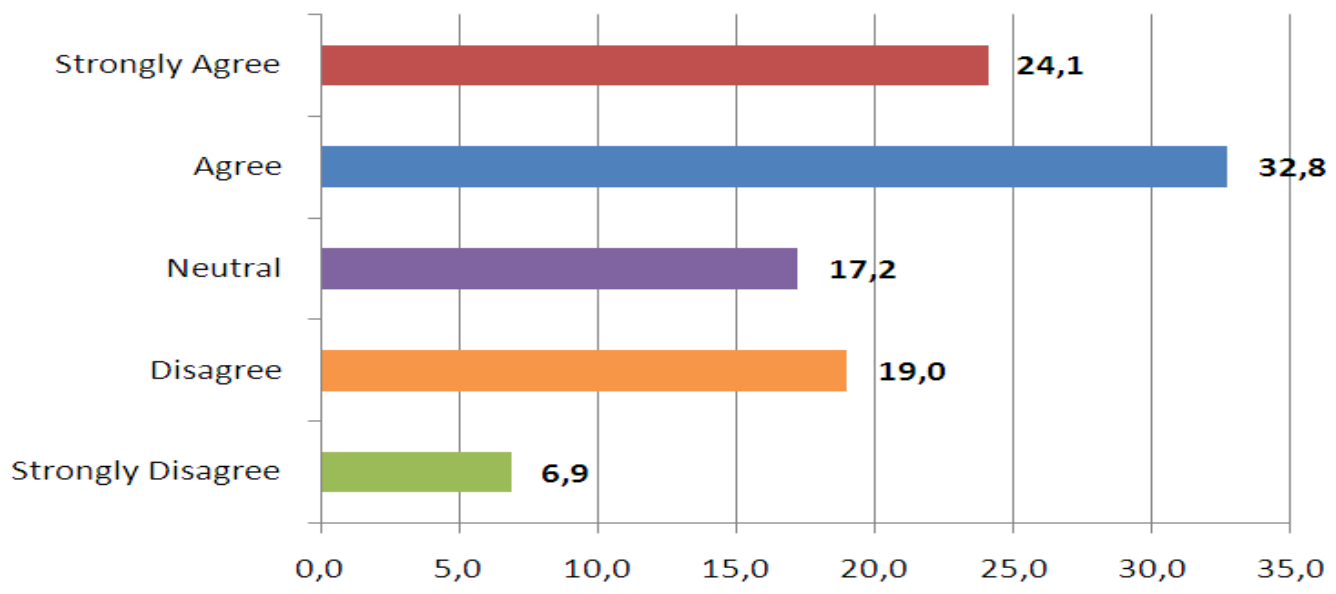

Fig. 4. Always offered the option of Islamic banking to Muslim clients

As shown in Figure 4, more than half (57\%) of the respondents reported that they always offered the option of Islamic banking to their Muslim clients. Over a quarter $(26 \%)$ responded that they do no offer their Muslim clients the Islamic offering. Riba in Islam is strictly prohibited and Muslim must abstain from paying or receiving it. Islamic Banking products are free from Riba and, as such, need to be offered to Muslim clients, as it meets their religious needs. If a client is not offered the Islamic banking products and later finds out that the bank has this offering, it could create a reputational risk for the bank. Another risk is that if the client is approached by a competitor bank, they could switch banks thinking that FNB does not offer Islamic Banking. 


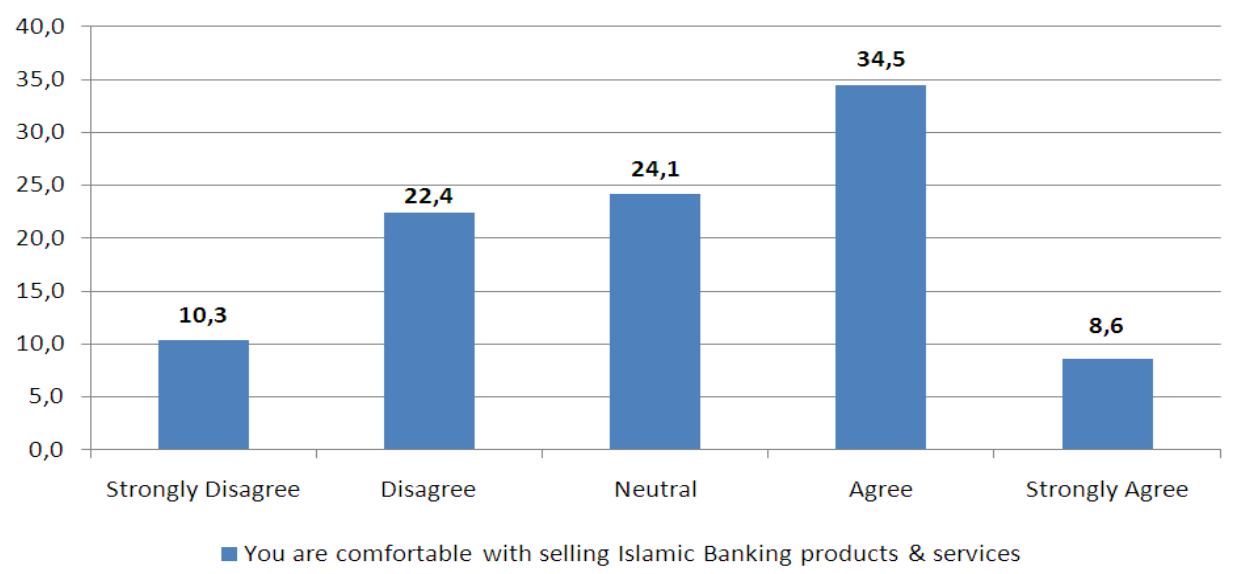

Fig. 5. Are you comfortable with selling Islamic banking products

As shown in Figure 4, about a third (32.7\%) of the respondents reported that they were not comfortable with selling Islamic banking products,

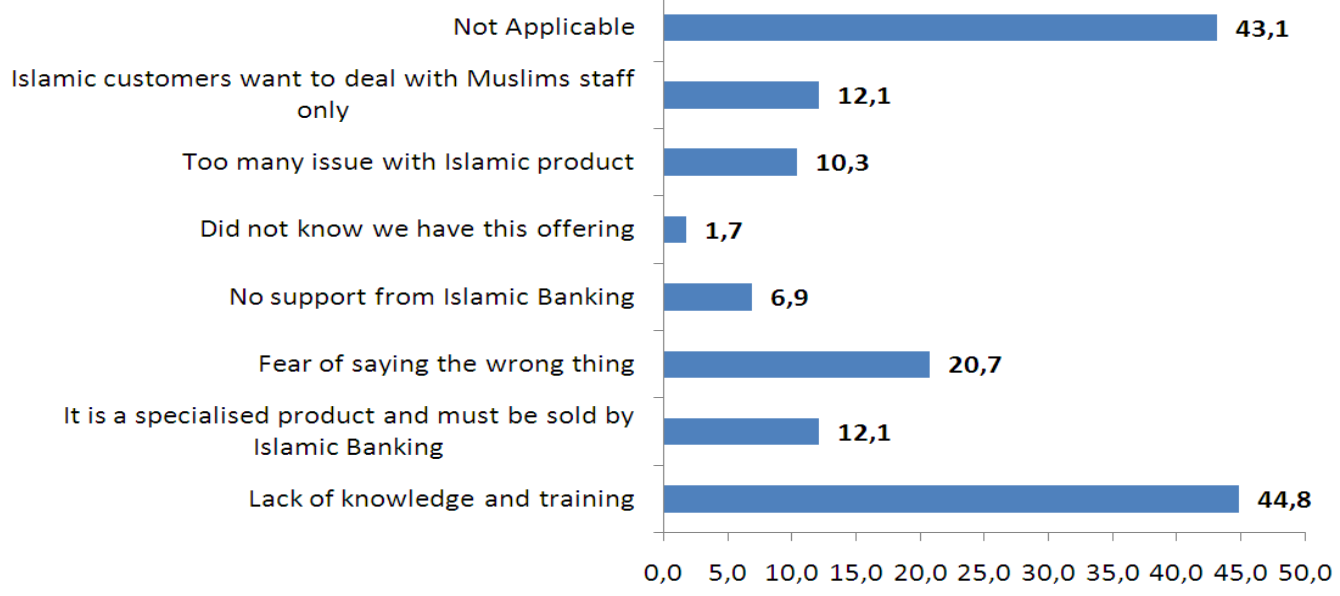

Fig. 5. Reasons for not being comfortable regarding Islamic banking

Further to the previous question regarding how comfortable the respondents were with selling Islamic banking products, the respondents were asked a follow up question as to the reasons why they were not comfortable selling Islamic products. Majority of the respondents $(44.8 \%)$ stated that they were not comfortable because of a lack of knowledge and training, followed by $20.7 \%$
$43.1 \%$ were comfortable selling the products and just under a quarter $(24.1 \%)$ were neutral in their response.

Table 4. Attitude towards Islamic banking

\begin{tabular}{|c|c|c|c|c|c|}
\hline Statements & SD & D & $\mathrm{N}$ & A & SA \\
\hline FNB Islamic banking should sell, service and manage FNB Islamic clients & 3.5 & 7.0 & 21.1 & 38.6 & 29.8 \\
\hline You feel you get enough support from the Islamic banking team & 8.6 & 20.7 & 22.4 & 25.9 & 22.4 \\
\hline You get the recognition for opening and managing Islamic banking products & 10.3 & 22.4 & 39.7 & 17.2 & 10.3 \\
\hline You have targets that you have to achieve for Islamic anking products & 10.3 & 32.8 & 43.1 & 6.9 & 6.9 \\
\hline Muslim clients feel more comfortable with sales people that are Muslim & 3.4 & 10.3 & 22.4 & 37.9 & 25.9 \\
\hline $\begin{array}{l}\text { You have Muslim clients that are not comfortable dealing with sales people if they are not from } \\
\text { FNB Islamic banking }\end{array}$ & 5.2 & 19.0 & 39.7 & 31.0 & 5.2 \\
\hline
\end{tabular}

Source: * $\mathrm{SD}=$ Strongly Disagree, $\mathrm{D}=$ Disagree, $\mathrm{N}=$ Neutral, $\mathrm{A}=$ Agree, $\mathrm{SA}=$ Strongly Agree.

There were 6 Likert-type statements that were asked to the respondents regarding their attitude towards the current way that Islamic banking is being sold and managed. Results varied per ques- tion. For question one, 68.4 per cent of the respondents felt that Islamic banking should sell, service and manage FNB Islamic clients, whereas only 10.5 per cent felt that the current model works. This is surpris- 
ing, as the primary distribution channel for Islamic banking feels that Islamic banking should sell and manage their own product which is totally against what the current model promotes.

The second question related to whether Islamic banking provides enough support to the sales team and here the results were mixed with 48.3 per cent agreeing, 29.3 per cent disagreeing and 22.4 per cent being neutral. Sales teams require the necessary support on products, as this will ensure that they feel comfortable in selling the products and services.

Over a quarter $(27.5 \%)$ stated that they get recognition for opening and managing Islamic banking products, however, $32.7 \%$ disagreed and $39.7 \%$ were unsure. For sales staff to actively sell products, they have to get the recognition for doing the sale. According to the above analysis, a minority of respondents stated they receive recognition which could mean that the majority will not actively sell Islamic products because they do not get the recognition for the sale.

Only $13.8 \%$ agreed that they had targets to achieve for Islamic banking products with $43.1 \%$ stating that they were unsure and also $43.1 \%$ disagreed that they had any Islamic banking targets. Sales teams are driven to achieve targets and if only a minority of the respondents can confirm that they have targets, then, this could result in them not actively selling Islamic banking products, as they will focus their efforts on products that they do have targets for.

When asked whether the sales staff felt that the Muslim clients felt more comfortable in dealing with sales staff that was of the Muslim faith, over half $(63.8 \%)$ of the respondents agreed with this statement, whereas only $13.7 \%$ disagreed with the statement. Another statement asked the respondents if they have Muslim clients that are not comfortable dealing with sales people if they are not from FNB Islamic banking. 36.2\% agreed, 39.7\% were unsure and $24.2 \%$ disagreed that Muslim clients feel more comfortable with dea-ling with FNB Islamic banking only.

As shown in Figure 7, 68.4 per cent of the respondents agreed or strongly agreed that they had Muslim clients in their base that had conventional banking products and not Islamic banking products. This means that these clients were either not offered Islamic banking, do not know that FNB has Islamic banking or that the Islamic banking offering did not meet their needs as a client. Based on the findings in this section, it would appear that the current hybrid model that Islamic banking is using may not be the most effective manner in which they sell their pro-ducts and services.

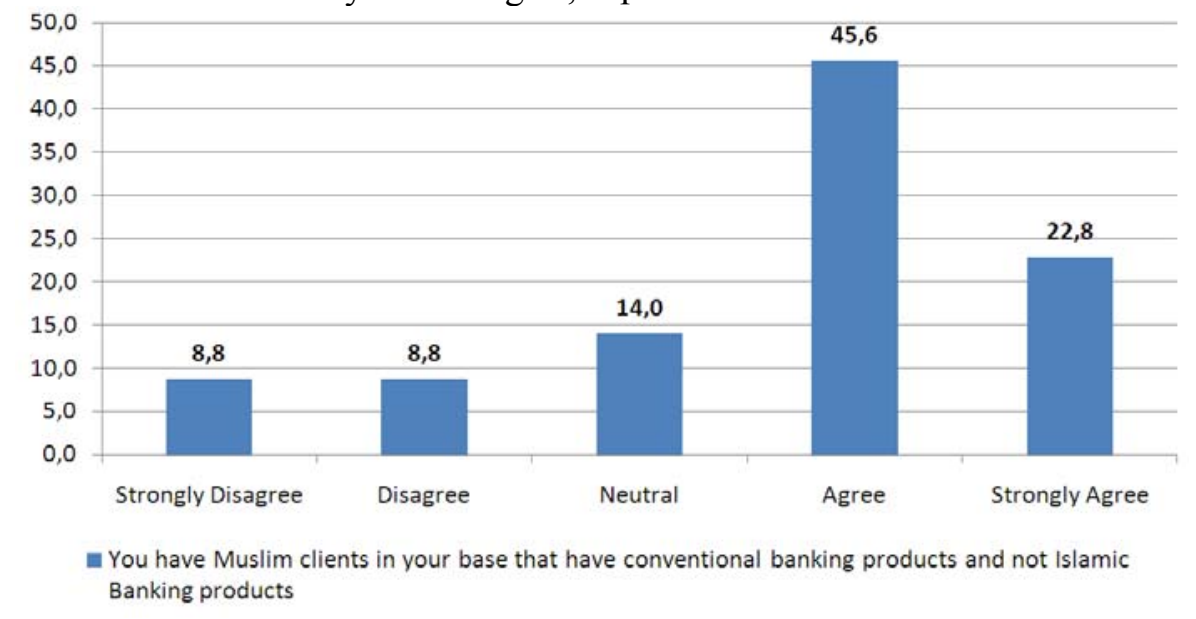

Fig. 7. Do you have Muslim clients in your base that have conventional banking products and not Islamic banking products?

\section{Conclusion}

There is definitely a need for Islamic banking, as well as it is important to meet the needs of a client, however the perception of the sales staff is that Islamic banking products and services are more complicated when comparing it to the conventional products and services. There is an overall lack of knowledge and understanding of Islamic banking by the sales staff, as majority of the respondents have a poor understanding of Islamic banking and more than a third of the respondents reported that they were not comfortable with selling Islamic banking products and services. The hybrid model that Islamic banking uses seems to have conflicting views and has an overall negative perception by the respondents. Majority of the respondents feel that Muslim clients feel more comfortable with sales people that are Muslim and the respondents felt that Islamic banking should sell, service and manage the FNB Islamic clients.

Based on the findings of this study, it clearly reflects that there are challenges that FNB Islamic banking face with regards to the sales force and that the overall perception of Islamic banking in FNB is negative. If FNB Islamic banking does want to be 
the market leader for Islamic banking in South Africa, then, there needs to be a change in the overall perception of Islamic banking within the group. These changes will not in any way dilute the excellent brand that FNB has, but it will rather improve and build on the existing platform that it currently has.

\section{Recommendations}

Based on the finding, the following recommendations are made based on the four broad categories:

- Islamic windows operate within a bigger conventional bank and leverage of the various areas that are available to them. One of the key areas that Islamic windows leverage to give them an advantage in terms of footprint is the bigger banks distribution channels, i.e., the branch network. As most of the sales force are non-Muslim, it is imperative that there is no negative perception of the Islamic banking products, as this may lead to the lack of sales and growth in this area.

- It is recommended that Islamic banking develops a campaign that is aimed at educating and sensitizing the sales force about Islamic banking products and services, as well as the industry on the whole. By educating and creating the awareness, it will remove any negative perception of Islamic banking and will also show the benefits of selling Islamic banking products for the sales consultant, the client and the bank as well. Islamic banking management should also engage with the various stakeholders so that the awareness is created at management level as well. Generally, if you get buy-in from management, it is easier to get those below them to buy-in as well.
- It is recommended that Islamic banking creates an increased awareness to the sales force about the benefits of Islamic banking through the use of dedicated Islamic trainers. The role of the dedicated Islamic trainers is vital in creating awareness at the branch level, as they will conduct regular training sessions. This will result in an increase level of awareness of Islamic banking and support for the sale staff. Islamic banking management should also conduct road shows on Islamic banking so that the sales force can get an idea as to the performance and strategy that Islamic banking is following.

- Currently, Islamic banking utilizes a hybrid model which entails that the conventional branches sell Islamic Banking products and services on their behalf. Whilst this model has many benefits, it seems to have, however created a negative perception and confusion for the sales staff. As majority of the sale staff feel that Islamic banking should sell, service and manage their own client, if the current hybrid model is to be continued, then, it is recommended that Islamic banking ensure that this model is backed by a clear service level agreement (SLA) between Islamic banking and the branch network. The SLA needs to ensure that the following is included:

- Sales staff are recognized for selling and managing Islamic banking products and services.

- Sales staff have targets specifically for Islamic banking products and services.

- There should be no arbitrage between Islamic banking \& conventional banking products except if it conflicts with Shariah.

- Clear guidelines as to the roles and responsibilities of all stakeholders.

\section{References}

1. Abdul-Rahman, Y. (2010). The art of Islamic banking and finance. Hoboken, N.J.: Wiley, pp. 43-44, 77-78, $196-200$.

2. Allison, E. (2012). What does "Internal" Customer Service Really Mean? [online] Elaineallison.com. Available at: http://elaineallison.com/what-does-internal-customer-service-really-mean [Accessed 26 Apr. 2015].

3. Arshad, M., Aslam, S., Razi, A. and Ali, S. (2011). A comparative analysis of Bankers Perception on Islamic Banking in Pakistan. Lahore: The University Of Lahore, pp. 1-12.

4. Ayub, M. (2007). Understanding Islamic finance. Hoboken, NJ: John Wiley \& Sons, p. 10, pp. 21-22, 322.

5. Azjen, I. (1982). Consistency in Social Behavior, The Ontario Symposium, 2, pp. 3-5.

6. Cahn, S. (2012). Adam Smith and Capitalism for Beginners. [online] Prometheus Unbound. Available at: https://santitafarella.wordpress.com/2012/07/04/adam-smith-and-capitalism-for-beginners/ [Accessed 8 Apr. 2015 ].

7. Ernst \& Young, (2013). World Islamic Competitiveness Report 2013-2014. Ernst \& Young, pp. 4-8. Available at: http://emergingmarkets.ey.com/wp-content/uploads/downloads/2013/12/World-Islamic-Banking-CompetitivenessReport-2013-14.pdf [Accessed 4 Mar. 2015].

8. Farias, S. (2010). Internal Marketing (IM): a literature review and research propositions for service excellence, Brazilian Business Review, 7 (2), pp. 99-115.

9. Hamid, A. and Nordin, N. (2001). A study on Islamic Banking Education and Strategy or the New Millenium Malaysian Experience. International Journal of Islamic Financial Services, Vol. 2 (4), pp. 1-10.

10. Haque, (2009). Factor Influences Selection of Islamic Banking: A Study on Malaysian Customer Preferences, American Journal of Applied Sciences, 6 (5), pp. 922-928.

11. Haque, A. (2010). Islamic Banking in Malaysia: A Study of Attitudinal Differences of Malaysian Customers, European Journal of Economics, Finance and Administrative Sciences. Available at: http://irep.iium.edu.my/3867/1/ejefas_18_01 (Islamic_Bank).pdf [Accessed 23 Apr. 2015]. 
12. Hassan, H. and Kabir, F. (2011). Customers' attitude toward Islamic banking: In the case of Bangladesh. Available at: http://ssrn.com/abstract=1753526 [Accessed 25 Mar. 2015].

13. HBMSU. (2014). Islamic Banking Growth, Efficiency \& Stability. DCIBF Annual Report 2014. Available at: http://www.dcibf.ae/system/files/DCIBF_Report_English.pdf [Accessed 4 Jun. 2015].

14. Hbzbank.co.za. (2015). Islamic Banking Explained. Available at: https://www.hbzbank.co.za/ [Accessed 21 Apr. 2015$].$

15. Institute of Islamic Banking and Insurance. (2015). Islamic Financial System. Available at: http://www.islamicbanking.com/islamic-finance.aspx [Accessed 27 Mar. 2015].

16. Investorwords. (2015). What is Consumer? definition and meaning. Available at: http://www.investorwords.com/1055/consumer.html [Accessed 25 Mar. 2015].

17. Joseph, C. (2015). What Is an Internal Customer \& a External Customer? Available at: http://smallbusiness.chron.com/internal-customer-external-customer-11698.html [Accessed 26 Apr. 2015 ].

18. LaMarca, N. (2011). The Likert Scale: Advantages and Disadvantages. Available at: https://psyc450.wordpress.com/2011/12/05/the-likert-scale-advantages-and-disadvantages/ [Accessed 25 Apr. 2015 ].

19. Merriam-webster.com. (2015). Perception. Available at: http://www.merriam-ebster.com/dictionary/perception [Accessed 26 Apr. 2015].

20. Rao, V. and Narayana, P. (1987). Organization theory and behavior. New Delhi: Konark, pp. 329-330.

21. Sanusi, L. (2011). Islamic finance in Nigeria: issues and challenges. 1st ed. [ebook] Leceister: Markfield Institute of Higher Education, p. 5.

22. Sekaran, U. and Bougie, R. (2013). Research methods for business. 6th ed. Chichester, West Sussex: Wiley, pp. 2, 96, 162-163, 240-241.

23. Shanmugam, B. and Zahari, Z. (2009). A primer on Islamic finance. Charlottesville, Va.: Research Foundation of CFA Institute, pp. 11, 20.

24. Suliman, A. (2015). Islamic Term Deposit Training.

25. Usmani, M. (2002). Meezan Banks Guide to Islamic Banking. Karachi: Darul Ishaat, pp. 7-9, 12, 87-96, 98, 147-149, 155.

26. Venardos, A. (2005). Islamic banking \& finance in South-east Asia. Hackensack, NJ: World Scientific, pp. $34,62$.

27. Vizcaino, B. (2013). Britain aims to be first Western country to issue sovereign Islamic bond. Available at: http://uk.reuters.com/article/2013/10/29/uk-britain-finance-islamic-idUKBRE99S00I20131029 [Accessed 27 Feb. 2015].

28. WISEGEEK. (2015). What Factors Affect Product Perception? Available at: http://www.wisegeek.com/whatfactors-affect-product-perception.htm [Accessed 24 Apr. 2015]. 